\title{
THE ANALYSIS OF FACTORS AFFECTING INDONESIA'S TEA EXPORT TO ENGLAND
}

\author{
Ririt Iriani Sri Setiawati ${ }^{1}$, Muctholifah $^{2}$, M.Taufiq ${ }^{3}$ \\ \{ririt.irianisri@gmail.com\} \\ ${ }^{1,2,3}$ Science of Economy, Development Study, Universitas Pembangunan Nasional \\ "Vetera.irianin" Jawa Timur, Surabaya, Indonesia
}

\begin{abstract}
Indonesia is an agricultural country, the role of agriculture and agribisinis can be used as a benchmark of success for national economic development, in terms of food security. The agribusiness sector is still able to generate foreign exchange, one of which is the tea commodity which has an important contribution in generating foreign exchange for the country. England is one of the biggest tea consuming countries in the world, therefore tea from Indonesia is in great demand, especially in the country of Queen Elizabeth. This research uses secondary data for 15 years, from 2000 to 2014 by using multiple linear regression analysis calculations to determine the simultaneous and partial influence of the dependent variable, namely the Export Value of Indonesia's Tea to England (Y), with the independent variable Tea Production Volume (X1 ), Exchange Rate (X2), England's Inflation (X3), Gross Domestic Product (X4). The results showed that simultaneously all independent variables (X) significantly affected the value of Indonesia's Tea Exports to England (Y) with a Fcount of $8.483 \geq$ Fable 3.48. While partially the Exchange Rate variable (X2) and Gross Domestic Product (X4) significantly influence the Indonesia's Tea Export Value to England (Y), while the Tea Production Volume variable (X1) and England's Inflation (X3) do not significantly influence the Export Value Indonesia's Tea to England (Y).
\end{abstract}

Keywords: Indonesia's Tea Export Value, Tea Production Volume, Exchange Rate, Inflation, Gross Domestic Product. 


\section{INTRODUCTION}

As an agricultural country, agriculture and agribusiness play major role to national economic development. The latter still has the ability to earn foreign exchange, to which one of them is tea commodity, that significantly contribute to such exchange for the country. In 1999 , the country's tea industry was predicted to employ 300,000 employees and support approximately 1.2 million people. Besides, such industry produced Gross Domestic Product (GDP) to the amount of approximately 1,2 billion, or $0.3 \%$ of total GDP for non oil and gas sector. Therefore, the development of agribusiness must be increased through agricultural development, since it contains high local aspect, and through the country agribusiness-based economic development. (Agriculture information data \& system center).

Tea becomes the world's one of favorable beverages. Demand to this commodity is relatively high. Other than its acceptable taste, this nutritious beverage, especially the ones originally produced in Indonesia, is able to maintain human's health since it contains catechin that has the highest active ingredients and antioxidant among others. With this strength, tea becomes the country's excellent export commodity. Also, Indonesia has suitable land resources with tea growing terms and is highly potential to expland such land as well as to increase the quality and quantity of the plant. However, the fact proves that the area of tea plantation was decreased during 2008-2012.

Indonesia is the $7^{\text {th }}$ of seven tea producer countries in the world. Other than the country's foreign exchange source, tea also contributes to the increase of income to companies as well as small plantations and provides employment that results in the increase of employees. For the last thirty three years, from 1979 to 2012, Indonesia's tea commodicty export has been experiencing relatively high fluctuation trend. Such fluctuation to the country's overall tea export, both volume and value, turns out to give zero influence to the export amount to England. However, for thirty years, such export has experienced relatively high fluctuation in total.(Zakariyah, Mochamad Y, Anindita R, 2013)

The production allocations to each abovementioned market may be optimized since the profit margin of tea $/ \mathrm{kg}$ from each production center to each market were variative. Different profit margin occurred because of variative sale price, cost (transportation, insurance, and administration) to each market as well as different production cost in each tea production center.(Setiawan, 2018)

Based on the aforementioned background, the authors formulate the problems in this research : ( 1 ) Is the volume of tra production, Dollar exchange rate to Rupiah, England inflation, English PDB, affected by Indonesia's tea export to England partially and simultaneously ? ( 2 ) Which are the most dominant factor to the value of Indonesia's tea export to England?

In consistent with the above Research Purpose, the Research Purpose of this research are ( 1 ) To find out the partial and simulataneous influence of tea production tea, Dollar exchange rate to Rupiah, England's inflation, England's PDB towards Indoensia's tea export value to England. ( 2 ) To figure out the ost dominant factor towards Indonesia's tea export to England.

\section{PREVIOUS RESEARCHES}

a) Mirwan Junaidi, 2005. “Analisis Faktor-Faktor yang Mempengaruhi Penawaran Ekspor Teh. Variabel bebas : produksi teh, harga teh domestik, harga ekspor teh, nilai tukar rupiah terhadap dollar AS, kondisi perekonomian pra dan pasca krisis (Dummy Variabel). Analysis tool : Error Correction Model (ECM). In the short term the 
independent variables that have a significant effect on the dependent variable are production growth, exchange rate growth, and pre-crisis (dummy) economic conditions. In the long run free variables that have a significant effect on the dependent variable of production growth, exchange rate growth and economic conditions pre-crisis and postcrisis (dummy).

b) Deasy Hollylucia. P, 2008. Analisis Faktor-Faktor yang Mempengaruhi Ekspor teh Indonesia. Independent variable: Indonesian tea export volume, area of tea plantations, tea production, domestic tea prices, foreign tea prices, the exchange rate of the rupiah against the dollar.

c) Rohayati Suprihatini, 2005. "Analisis Daya Saing Ekspor Teh Indonesia di Pasar Teh Dunia”. Independent variables: Indonesian Tea Export Volume, Indonesian Tea Production Amount, International Tea Prices, Rupiah Exchange Rate Against US Dollar, US GDP, Types of Tea to be exported. Analysis Tool: Analyzing Market Share (CMS). The results of his research are the value of Indonesian tea exports in 2001, mostly still in the form of raw materials in the form of bulk black tea and bulk green tea, each with a mastery of the export value share of 6 percent and 2.6 percent. While mastery of the share of the value of Indonesian tea exports in the form of downstream tea products, namely black tea packaging and packaged green tea, is still very low, each reaching only 1.4 percent and 0.2 percent.

d) Juliana, 2012. "Analisis Faktor-Faktor yang Mempengaruhi Ekspor Karet Indonesia ke Amerika Serikat”. Independent variables: Indonesian Rubber Export Volume, Indonesian Rubber Production Amount, International Rubber Prices, Rupiah Exchange Rate Against US Dollar, US GDP. Analysis Tool: Ordinary Least Square (OLS) Multiple Regression. The results of the research are that the variable changes in rubber production, the exchange rate and US GDP significantly affect the volume of rubber exports, while changes in the variable international rubber prices do not significantly affect the volume of rubber exports.

e) Venty Fitriany Nurunisa dan Lukman Mohammad Baga, 2012.

“Analisis Daya Saing dan Strategi Pengembangan Agribisnis Teh Indonesia”. Independent variables: Indonesian Rubber Export Volume, Indonesian Rubber Production Amount, International Rubber Prices, Rupiah Exchange Rate Against US Dollar, US GDP, Indonesian tea agribusiness competitiveness. Analytical Tools: a descriptive qualitative method for a commodity agribusiness system framework to describe the conditions of Indonesian tea agribusiness. Research Results: To support the formulation of a tea industry cluster development strategy in West Java, further research is needed on the readiness and development strategy in the form of a tea industry cluster design in West Java as a tea production center in Indonesia.

\section{THEORETICAL BASIS}

\section{International Trade}

International trade is a form of economic cooperation between two countries or more that is related to goods sale and purchase as well as service, which aims to establish a country's prosperity. In other term, international trade is defined as economic partnership in the form of trade conducted by a citizen in a country with the one in another country. In this case, citizen may be between a country's government and another one in the other country, between an individual and any government in a country, or between individual to any individual in a country. Recently, trade becomes significant economic activity. No countries in this world that 
does not involve itself in trade, in local, regional, and international stage. International trade includes transactional activities, like sale and purchase, both to and from a country (import and export) .(Hasoloan, 2013)

\section{Definition of Export.}

Export means a series of trade or goods delivery from a country to another one. So, export becomes a part of international trade.(Sedyaningrum, Suhadak, \& Nuzula, 2016)

Exports means to distribute goods, that are circulated in society, deliver them outside the country under governmental regulation, and expect payment in foregin exchange.(Benny, 2013)

\section{Production.}

An activity process to produce goods and service ( outpot ) by using a set of production factors ( input ) is the general definition for production. $\mathrm{N}$ other words, production means an activity aims to change a set of input to any amount of certain output. (Damanik 2015)

\section{Exchange Rate.}

According to Salvatore ( 1994 ), exchange rate means the amount of or priceof domestic currency of a foregin country, or, the ration between one unit of currency and the amount of another currency in a specific period.

Foreign echange means foreign currenct need to conduct international transaction. Meanwhile, exchange rate means the price of a country's currency thatis measured in another country's currency. (Fathul i, 2017)

\section{Inflation.}

Inflation means the process of Common price constant increase of goods in a specific period. (Hasoloan, 2013)

According to (Mahendra A, 2017), inflation refers to a continuous increase to common price due to. In general, inflation means the decrease of society's purchasing power since their income actually decrease too.( Wuri, 2018)

\section{Gross Domestic Product ( GDP ).}

GDP ( Gross Domestic Product) refers to the value of goods or service in a country. This also includes the one conducted by citizen or foreign people in such country.(Satria, Yasin, \& Suparti, 2015)

GDP means the market value of all final product and service produced in a country in a specific period.(Dynan \& Sheiner, 2011)

\section{RESEARCH METHOD}

\section{Data Type and Source}

The data used in this research is a type of secondary data that is data obtained or collected from agencies or institutions that are related in this research.

The data used in this research came from: The Central Statistics Agency (BPS) of East Java Province in the form of; data on production volumes of commodity exports to England, England GDP, England inflation. Bank Indonesia, Surabaya is in the form of data on the Rupiah exchange rate against the Dollar.(Damanik, 2015) 


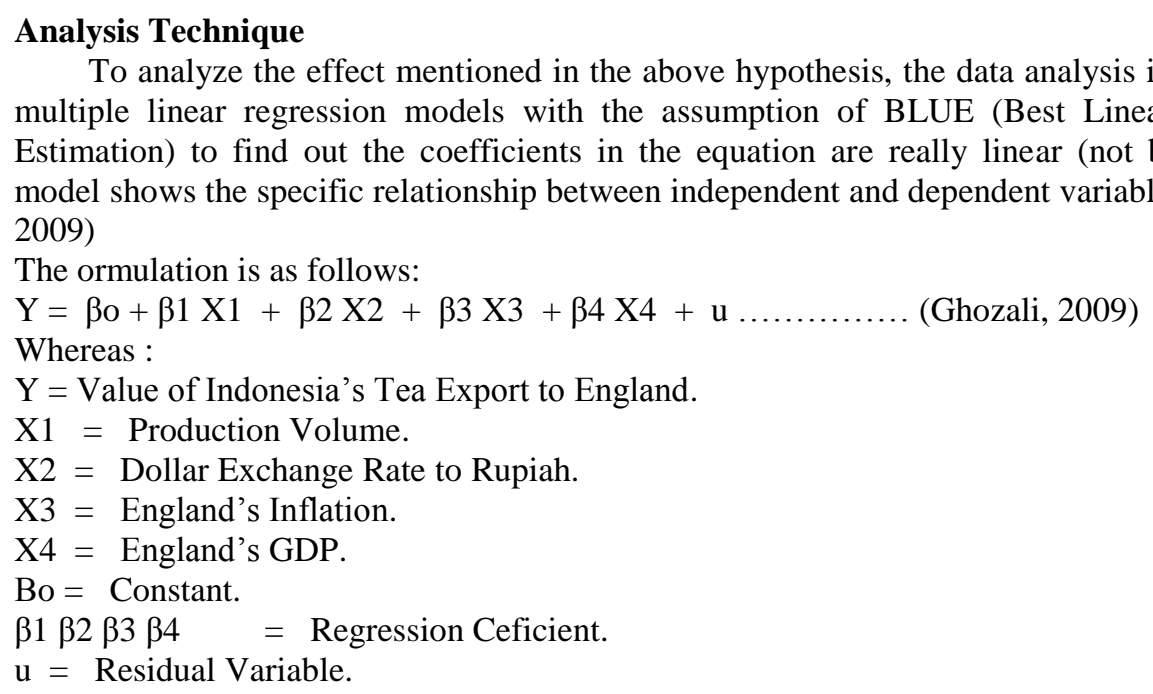

\section{Classical assumption Test}

The data analysis method used is multiple linear regression analysis model with the help of SPSS Software version 15.0. To produce a good model, regression analysis requires testing classic assumptions before testing hypotheses. The classic assumption testing includes the Autocorrelation test, the Multicollinearity test, and the Heteroscedasticity Test. (Ghozali, 2009)

\section{Autocorrelation Test}

According to Ghozali, 2005 "the autocorrelation test aims to test whether in the linear regression model there is a correlation between the error of the intruder in the period $t$ with the error of the intruder in the period t-1 (before)". The way that can be done to detect the presence or absence of autocorrelation is to do the Durbin Watson test.

The criteria for evaluating the occurrence of autocorrelation are:

1) $\mathrm{D}-\mathrm{W}$ value smaller than -2 means there is a positive correlation,

2) $\mathrm{D}-\mathrm{W}$ value between -2 to +2 means there is no autocorrelation,

3 ) $\mathrm{D}-\mathrm{W}$ value greater than +2 means there is a negative autocorrelation.

\section{Multicollinearity Test}

Multicollinearity test aims to test whether the regression model found a correlation between independent variables (independent). A good regression model should not occur correlation between independent variables. Multicollinearity can be detected by looking at the value of tolerance and variance inflation factor (VIF). The cut off value commonly used to indicate multicollinearity is a tolerance value $<0.10$ or equal to a VIF value $>10$ (Ghozali, 2009).

\section{Heteroscedasticity Test}

Heteroscedasticity test aims to test whether in the regression model there is an inequality of variance from the residuals of one observation to another. A good regression model is not heteroscedasticity. The way to detect the presence or absence of 
heteroscedasticity is to look at a plot graph between the predicted values of the dependent variable. Basic analysis to determine the presence or absence of heteroscedasticity, namely: 1) if there are certain patterns, such as the points that form a regular pattern (wavy, widened and then narrowed), then it indicates that heteroscedasticity has occurred,

2) if there are no clear patterns, and the points spread above and below the number 0 on the $\mathrm{Y}$ axis,

then heteroscedasticity does not occur. (Ghozali, 2005)

\section{Hypothesis Test}

The hypothesis to be tested in this research is related to the presence or absence of a significant effect of the independent variable on the dependent variable either partially or simultaneously. Testing the level of importance (Test of significance) is a procedure where the results of the sample are used to test the truth of a hypothesis with an analysis tool that is the suitability of the model test, the $\mathrm{T}$ test and the coefficient of determination $\left(\mathrm{R}^{2}\right)$. Statistical calculation is called statistically significant if the test of its statistical value is in a critical area (the area where Ho is rejected). Conversely, it is called insignificant if the test statistical value is in the area where Ho is received.

\section{F Test}

This $\mathrm{F}$ test is used to find out whether Ho is accepted or rejected, if $\mathrm{F}$ arithmetic $>\mathrm{F}$ table, then Ho is rejected Hi is accepted, meaning simultaneously the independent variable has an influence on the dependent variable, then vice versa $F$ arithmetic $<F$ table, then Ho is accepted $\mathrm{Hi}$ is rejected which means simultaneously the independent variable has no effect on the dependent variable. (Ghozali, 2005)

\section{T Test}

This $t$ test is used to find out whether Ho is accepted or rejected. If $\mathrm{T}$ arithmetic $>\mathrm{T}$ table or $\mathrm{T}$ arithmetic $<\mathrm{T}$ table then Ho is rejected and Hi is accepted, which means there is an influence between the independent variable and the dependent variable. Conversely, if $\mathrm{T}$ table $<\mathrm{T}$ count $<\mathrm{T}$ table then Ho is accepted and Hi is rejected which means there is no influence between the independent variable and the dependent variable. (Ghozali, 2005)

\section{RESULT AND DISCUSSION}

\section{Determinant Coefficient}

Based on the SPSS test results with the dependent variable Indonesia's Tea Export Value to England, the results obtained $\mathrm{R} \neg^{2}$ (R Square) = Coefficient coefficient of 0.886 meaning $88.6 \%$ of all observations showed the independent variable Tea Production Volume (X1), Exchange (X2), Inflation (X3), and GDP (X4) are able to explain the variation of the dependent variable namely the Value of Indonesia's Tea Exports to England (Y), the remaining $11.4 \%$ (obtained from $100 \%-88.6 \%$ ) is influenced by other factors that are not visible in the model or error.

Based on the SPSS test results with the dependent variable Indonesia's Tea Export Value to England, the results obtained $\mathrm{R} \neg^{2}$ (R Square) = Coefficient coefficient of 0.886 meaning $88.6 \%$ of all observations showed the independent variable Tea Production Volume (X1), Exchange (X2), Inflation (X3), and GDP (X4) are able to explain the variation of the dependent variable namely the Value of Indonesia's Tea Exports to England (Y), the 
remaining $11.4 \%$ (obtained from $100 \%-88.6 \%$ ) is influenced by other factors that are not visible in the model or error.

\section{Classical Assumption Test}

\begin{tabular}{|c|c|c|}
\hline Y Variable & $\begin{array}{c}\text { DW Tes } \\
\text { Score }\end{array}$ & Note \\
\hline $\begin{array}{c}\text { Value of Tea } \\
\text { Export }\end{array}$ & 0.777 & Uncertainty Area \\
\hline
\end{tabular}

Based on the SPSS processing results obtained DW Test value with Variable (Y) Tea Export Value of 0.777 with the provisions of $0-0.688$ (there is autocorrelation) $0.688-1,977$ (uncertainty area) 1,977 - 2,023 (no autocorrelation) 2,023 - 3,315 (no region pastian) 3,315 4 (there is an autocorrelation). Based on these data the value of 0.777 lies in the area of uncertainty.

\section{Multicolinearity}

\begin{tabular}{|c|c|c|c|c|}
\hline $\begin{array}{c}\mathrm{Y} \\
\text { Variable }\end{array}$ & $\mathrm{X}_{1}$ & $\mathrm{X}_{2}$ & $\mathrm{X}_{3}$ & $\mathrm{X}_{4}$ \\
\hline $\begin{array}{c}\text { Value } \\
\text { of Tea } \\
\text { Export }\end{array}$ & 4.761 & 4.807 & 4.273 & 8.928 \\
\hline
\end{tabular}

Then the results obtained after testing multiple linear regression analysis is known that of the variables in the Tea Export Value test where the VIF value is less than 10 so that in this regression model Multicollinear does not occur.

\section{Heteroscedasticity}

\begin{tabular}{|c|c|c|c|c|}
\hline $\begin{array}{c}\mathrm{Y} \\
\text { Variable }\end{array}$ & $\mathrm{X}_{1}$ & $\mathrm{X}_{2}$ & $\mathrm{X}_{3}$ & $\mathrm{X}_{4}$ \\
\hline $\begin{array}{c}\text { Value } \\
\text { of Tea } \\
\text { Export }\end{array}$ & 0.845 & 0.694 & 0.945 & 0.820 \\
\hline
\end{tabular}

Based on the results of SPSS processing with the dependent variable Tea Export Value obtained residual results greater than 0.05 (not significant), which means the residual value with the variables that explain does not have a significant correlation. So it can be concluded that the equation does not occur heterocedasticity.

\section{Simultaneous Hypothesis Test}

The $\mathrm{F}$ test was carried out to assess the effect of simultaneous Tea Production Volume, Exchange Rate, Inflation and GDP on the Value of Indonesia's Tea Exports to England. In the $\mathrm{F}$ test the hypothesis is carried out as follows:

H0: $\mathrm{a}=\mathrm{b} 1=\mathrm{b} 2=\mathrm{b} 3=0$, meaning that the variable Tea Production Volume, Exchange Rate, Inflation, and GDP have no significant effect on the value of Indonesia's Tea Exports to England.

$\mathrm{H} 1: \mathrm{a} \neq \mathrm{b} 1 \neq \mathrm{b} 2 \neq \mathrm{b} 3 \neq 0$, means that the variable Tea Production Volume, Exchange Rate, Inflation, and GDP have a significant effect on the value of Indonesi's Tea Exports to England 


\begin{tabular}{|c|c|c|}
\hline Y Variable & F Calculation & F Table \\
\hline Value of & 8.483 & 3.48 \\
Tea Export & & \\
\hline
\end{tabular}

Based on these results obtained $\mathrm{F}$ calculated Tea Export Value $=8.483 \geq \mathrm{F}$ table $=$ 3.48 then $\mathrm{Ho}$ is rejected and $\mathrm{Hi}$ is accepted, which means that overall the independent variables are Tea Production Volume (X1), Exchange (X2), Inflation (X3), and GDP (X4) simultaneously influence the Value of Indonesia's Tea Exports to England (Y).

\section{Partial Hypothesis Test}

T-test was conducted to find out how far the influence of an independent variable on the dependent variable partially. In the T-test the following hypotheses are used:

H0: $\mathrm{a}=\mathrm{b} 1=\mathrm{b} 2=\mathrm{b} 3=0$, meaning that the variable Tea Production Volume, Exchange Rate, Inflation, and GDP have no significant effect on the value of Indonesia's Tea Exports to England.

H1: $\mathrm{a} \neq \mathrm{b} 1 \neq \mathrm{b} 2 \neq \mathrm{b} 3 \neq 0$, meaning that the variable Tea Production Volume, Exchange Rate, Inflation, and GDP have a significant effect on the value of Indonesia's Tea Exports to England.

This test is done by comparing the significance of the T-count with the T-table with conditions:

1) if $\mathrm{t}$-count $<\mathrm{t}$-table, then $\mathrm{H} 0$ is accepted and $\mathrm{Ha}$ is rejected for $\alpha=2.5 \%$ or significance $>$ 0.025 ,

2) if t-count $>\mathrm{t}$-table, then $\mathrm{H} 0$ is rejected and $\mathrm{Ha}$ is accepted for $\alpha=2.5 \%$ or significance $<0.025$.

\begin{tabular}{|c|c|c|}
\hline $\begin{array}{c}\text { Y Variable of } \\
\text { Tea Export } \\
\text { Value }\end{array}$ & T-Calculation & T-Table \\
\hline $\begin{array}{c}\text { Tea Production } \\
\text { Value }\end{array}$ & 0.561 & 2.228 \\
\hline Exchange Rate & 4.457 & 2.228 \\
\hline Inflation & 0.832 & 2.228 \\
\hline GDP & 6.963 & 2.228 \\
\hline
\end{tabular}

Based on the calculation, the obtained variable Tea Production Volume (X1) t-count of $0.561 \leq \mathrm{t}$ table of 2.222 then Ho is accepted and $\mathrm{Hi}$ is rejected, at a significant level of $5 \%$, so that partially Tea Production Volume (X1) does not significantly positive effect on Value Indonesia's Tea Exports to England (Y). This is supported also by the significance value of Tea Production Volume (X1) of 0.587 which is greater than 0.05 .

Based on the calculation, the result of the Exchange Rate (X2) t-count of $4.457 \geq t$ table is 2.282 then $\mathrm{Ho}$ is rejected and $\mathrm{Hi}$ is accepted, at a significant level of 5\%, so that the Exchange Rate (X2) has a significantly positive effect on the value of Indonesia's Tea Exports to England (Y). This is supported also by the significance value of the Exchange Rate (X2) of 0.003 which is smaller than 0.05 .

Based on the calculation, the result of Inflation (X3) t-count of $0.832 \leq \mathrm{t}$ table is 2.222 then $\mathrm{Ho}$ is accepted and $\mathrm{Hi}$ is rejected, at a significant level of 5\%, so partially Inflation (X3) has a 
significantly positive effect on the value of Indonesia's Tea Exports to England (Y). This is supported also by the significance value of Inflation (X3) of 0.425 which is greater than 0.05 . Based on calculations, the results of the variable GDP (X4) t-count of $6.963 \geq t$ table of 2.222 then $\mathrm{Ho}$ is rejected and $\mathrm{Hi}$ is accepted, at a significant level of 5\%, so partially GDP (X4) has a significantly positive effect on the value of Indonesia's Tea Exports to England (Y). This is supported also by the significance value of GDP (X4) of 0.045 which is smaller than 0.05 .

\section{DISCUSSIONS}

Based on the results of the analysis obtained, the authors can draw the conclusion that :

1. Overall independent variables namely Tea Production Volume (X1), Exchange Rate (X2), England's Inflation (X3), and Gross Domestic Product (X4) simultaneously and significantly affect the value of Indonesia's Tea Exports to England

( Y ).

2. Partially Tea Production Volume (X1) has no significant (not significant) positive effect on the value of Indonesian Tea Exports to the United Kingdom (Y). This is because Indonesia not only exports tea to England, but also to other countries, besides that England only requires the amount of tea exports it needs and no more so that the increase and decrease in the amount of Indonesia's tea production does not affect the volume of Indonesia's tea exports to England so that the effect is not too significant for the value of Indonesia's Tea exports to England. This theory is also supported by the Comparative Excellence Theory put forward by David Ricardo which does not question the possibility of countries that have absolutely no advantage in producing goods against other countries, for example developing countries against developed countries. And this research is supported by previous research conducted by (Mirwan Junaidi, 2005).

3. Partially Exchange Rate (X2) has a significant (significant) positive effect on the value of Indonesia's Tea Exports to England (Y). This is because if the Rupiah exchange rate against the Dollar decreases, the Rupiah value will also strengthen so that it will indirectly affect the level of consumer demand for Indonesian Tea exports. The increasing demand for tea will indirectly affect the increase in the value of Indonesian Tea exports. This theory is also supported by the theory of demand where the lower the price of an item, the more demand for that item. Conversely the higher the price of an item, the less demand for that item. And this research was supported by previous researchers conducted by (Juliana, 2012).

4. Partially Inflation (X3) has no significant (not significant) positive effect on the value of Indonesian Tea Exports to England (Y). This is due to the higher inflation in England due to the increasing number of entrepreneurs or producers selling goods or products to the country so that many producers increase the amount of their exports so that the Tea Export Value will increase. However, inflation in England is increasing causing the Volume of Tea Export Value in Indonesia to decrease or decrease, this is because many farmers cannot add to the amount of goods to be exported due to high export costs and lack of demand for existing goods. So that inflation does not affect the demand for tea exports from Indonesia and does not significantly influence the value of Indonesian tea exports to England. This theory is also supported by the theory of supply where the higher the price of an item, the more the amount of the item will be offered to the seller. Conversely the lower the price of an item, the less the number of goods offered by the seller. And this research is supported by previous research conducted by (Mirwan Junaidi, 2005). 
5. Partially, the Gross Domestic Product (X4) has a significant (significant) positive effect on the value of Indonesian Tea Exports to the United Kingdom (Y). This is because if the Gross Domestic Product in England rises, the income of the British people will also rise so that it will indirectly affect the level of consumer demand for Indonesian Tea exports. The increasing demand for tea will indirectly affect the increase in the value of Indonesian Tea exports. This theory is also supported by the theory of demand where the lower the price of an item, the more demand for that item. Conversely the higher the price of an item, the less demand for that item. And this research is supported by previous research conducted by (Juliana, 2012).

6. Then to find out which variable has the most dominant influence of the four independent variables on the Indonesian Tea Export Value to England: Tea Production Volume (X1), Exchange Rate (X2), England's Inflation (X3), and Gross Domestic Product (X4) can be known by looking at the greatest partial determination coefficient, which in the calculation is indicated by the variable Rupiah Exchange Rate Against the Dollar (X2) with a partial determination coefficient (r2) of 0.839 or $83.9 \%$.

\section{CONCLUSIONS}

Based on the analysis results that have been described, the following conclusions can be drawn :

1. Simultaneous influence between independent variables Tea Production Volume (X1), Exchange Rate (X2), Inflation (X3), and Gross Domestic Product (X4) have a simultaneous and real effect on the value of Indonesian Tea Exports to England (Y)

2. By looking at the test results of the significance of the independent variable on the value of Indonesia's Tea Exports to England, it can be seen that the Exchange Rate (X2) and Gross Domestic Product (X4) variables are significantly influential on the Value of Indonesia's Tea Exports to England (Y). This is because if the exchange rate of the Rupiah against the Dollar decreases, the Rupiah value will also strengthen indirectly which will affect the level of consumer demand for Indonesian tea exports, and the increase in England's Gross Domestic Product will cause England people's income to also rise so that it will indirectly affect the level consumer demand for Indonesia's Tea exports. The increasing demand for tea will indirectly affect the increase in the value of Indonesia's Tea exports.

3. By looking at the test results of the significance of the independent variable on the value of Indonesia's Tea Exports to England, it can be seen that the Production Volume (X1) and Inflation (X3) variables are variables that do not significantly influence the Indonesia's Tea Export Value to England (Y). This is because Indonesia not only exports tea to England but also to other countries, besides that tea production from Indonesia is also widely consumed by the Indonesian people themselves so that the increase and decrease in the amount of Indonesia's tea production does not affect the volume of Indonesian tea exports to England so that its influence not too significant to the value of Indonesia's tea exports to England, and the decline in England's inflation does not affect the increase in consumption of tea exports from Indonesia, because the British people not only consume tea but also coffee and other commodities as substitute goods. So, it does not affect the demand for tea exports from Indonesia and does not significantly influence the value of Indonesia's tea exports to England.

4. The most dominant variables influencing the four independent variables on the value of Indonesia's Tea Exports to England: Tea Production Volume (X1), Exchange Rate (X2), 
England's Inflation (X3), and Gross Domestic Product (X4) are indicated by the Rupiah Exchange Rate Against Dollar (X2).

\section{SUGGESTIONS}

Based on the conclusions above, the following are some suggestions for consideration as follows :

1. The government needs to maintain and increase the stability of the Rupiah against the Dollar while at the same time giving more attention to policies related to the Exchange rate because even though the strengthening of the Dollar Exchange Rate can affect the demand for tea exports from Indonesia it will have a negative impact on the Indonesian economy.

2. The government needs to maximize the commodity of tea exports and reduce the import of tea that can be produced alone in the country and reduce the import of expensive tea from other countries, by implementing various regulations that can support this. The increased performance of various export commodities, especially tea, will result in additional foreign exchange for the country and reducing imports could minimize the reduction in foreign exchange so that economic stability can be maintained.

3. Climate change can adversely affect tea plants in Indonesia so that government policies to prevent illegal logging must always be tightened and reinforced for offenders and the greening movement to reduce the effects of global warming at this time must always be instilled an awareness of each individual..

4. For further research, other factors should be added as well as adding time vulnerable to the research in order to obtain better research results.

\section{REFERENCES}

Benny, J. (2013). Ekspor Dan Impor Pengaruhnya Terhadap Posisi Cadangan Devisa Di Indonesia. Jurnal Emba. ISSN: 2303-1174, 1(4), 1-10. Retrieved from http://ejournal.unsrat.ac.id/index.php/emba/article/view/2920/2471

Damanik, D. A. (2015). Faktor faktor Yang mempengaruhi Produksi Teh.

Dynan, K., \& Sheiner, L. (2011). GDP as a Measure of Economic. International Centre for Economic Research, 1-53.

Fathul i, M. (2017). SUKU BUNGA SBI TERHADAP INDEKS HARGA SAHAM GABUNGAN LQ-45 PERIODE TAHUN 2009-2013. VI.

Ghozali, I. (2009). Ekonometrika Teori, Konsep dan Aplikasi dengan Program IBM SPSS 24. Semarang: Universitas Diponegoro Press.

Hasoloan, J. (2013). Peranan Perdagangan Internasional Dalam Produktifitas Dan Perekonomian. Jurnal Ilmiah Pend. Ekonomi, 1(2), 102-112.

Mahendra A. (2017). Analisis Pengaruh Jumlah Uang Beredar, Suku Bunga Sbi, Nilai Tukar $\begin{array}{lllll}\text { Terhadap Tingkat Inflasi. Media } & \text { Ekonomi, } & \text { 18(2), } & 49 .\end{array}$ https://doi.org/10.25105/me.v18i2.2251

Satria, I., Yasin, H., \& Suparti. (2015). Proyeksi Data Produk Domestik Bruto (Pdb) Dan Foreign Direct Investment (Fdi) Menggunakan Vector Autoregressive (Var). 4, 895905.

Sedyaningrum, M., Suhadak, \& Nuzula, N. F. (2016). Pengaruh Jumlah Nilai Ekspor, Impor Dan Pertumbuhan Ekonomi Terhadap Nilai Tukar Dan Daya Beli Masyarakat Di Indonesia. Jurnal Administrasi Bisnis, 34(1), 114-121. Retrieved from 
Scientific Journal of Science of Economy, Development Study, March 2017

http://administrasibisnis.studentjournal.ub.ac.id/index.php/jab/article/download/1324/1 709

Setiawan, F. . (2018). Analisis Daya saing Ekspor Teh indonesia di pasar dunia. Universitas Islam Indonesia, 10(2), 1-15.

Wuri, J. (2018). Fluktuasi Kurs Valuta Asing Di Beberapa Negara Asia Tenggara. EXERO : Journal of Research in Business and Economics, 1(1), 1-22. https://doi.org/10.24071/exero.2018.010101

Zakariyah, Mochamad Y, Anindita R, B. N. (2013). Daya Saing Teh Indonesia Di Pasar Internasional. Economics Development Analysis Journal, 2(4), 29-37. https://doi.org/10.15294/edaj.v2i4.3214 
Scientific Journal of Science of Economy, Development Study, March 2017 